\title{
Personality Traits and Sales Effectiveness: The Life Insurance Market in Poland
}

\section{Andrzej Janowski ${ }^{1}$}

\begin{abstract}
Within organizations in industrialized countries, the quality of human resources tends to become a major issue on the path to achieving a competitive advantage. According to the author's research, the implementation of the five-factor model of Costa and McCrae provides the solution for the abovementioned problem. This article demonstrates the crucial utility of the five-factor model of Costa and McCrae in the context of life insurance industry effectiveness from both the theoretical and practical perspectives based on a case study of the four largest life insurance companies 796 most effective agents. Results imply the existence of a positive correlation between the level of the selected personality traits intensities and the life insurance agent's sales efficiency. Moreover, as levels of the personality traits of "openness to experience," "consciousness," "agreeableness" and "neuroticism" are the predictors of life insurance company effectiveness, there are fundamentals for induction to be appropriate for the whole retail financial sector human resources management system.

Keywords: competitive advantage, efficiency, human performance, management, organization, personality traits.
\end{abstract}

\section{INTRODUCTION}

In the sciences of management, the maxim, stating that behavior constitutes the consequence of the characteristics of a person and a situation, is considered as a truism. However, when going beyond the framework of generalization, it continuously constitutes an area of many controversies (Lucas \& Donnellan, 2009). There are inveterate causes of this discourse (Judge \& Zapata, 2014) and the controversy is based on two of the most frequently quoted criticisms concerning the relation of an individual and

1 Andrzej Janowski, Ph.D Eng., Bydgoszcz University of Technology and Life Sciences, Fordonska str. 430, 85-796 Bydgoszcz, Poland, e-mail: andrzej.janowski@utp.edu.pl. 
external determinants: measures of personality traits possess a relatively modest predictive value in the context of the comprehensive behaviours of an individual (Bratton \& Gold, 2017). Furthermore, their explanatory value is not supported by an adequate taxonomic process (Funder, 2006). In the case of the latter problem, the claim seems to be justifiable that through research, more significant progress was made in the classification and determination of personality traits rather than of situational factors, and situational variables tested in the research published are almost complete in an ad hoc perspective.

In the same manner, Buss (2009) claims that a nearly total lack of development in the area of the conceptualization of a situation in a nonarbitrary manner constitutes one of the most essential obstacles. Even in the case of uniqueness, no assumption is justifiable that a conceptual foundation that includes a situational context cannot be developed as a predictor of social (Harasym, Rodzinka \& Skica, 2017) or organizational behaviors (Joshi \& Roh, 2009; Trevino, 1986). Moreover, concerning the previous criticism, some researchers undermine the value of the scientific achievements of the abovementioned perspective. Wirdamulia and Afiff (2013) argue that individual differences represent in fact a modest contribution to the explanation of human behaviors.

At present, approaches to the usefulness of personality traits, in the context of the determination of effectiveness in relation to the previous critical remarks, emphasize that in the 1950s-1960s researchers focused on the validation of the personality inventory (Murphy \& Dzieweczynski, 2005) as an index of future professional success, which is also legitimized in the 21st century. Moreover, further deeper analysis allows us to find an internal contradiction among the protagonists of a negative evaluation of personality traits in relation to organizational effectiveness (Hogan, 2007; Ones, Dilchert, Viswesvaran \& Judge, 2007; Roberts, 2009), although just in the earlier studies by the present proponents of the theories of traits (Barrick, Mount \& Judge, 2001). Criticisms can also be found regarding its validation.

According to the above-mentioned discourse, I have identified major gaps that limit theory development (empirical, methodical and theoretical ones). This paper allows us to enrich the human resource management theory through a contribution that fills these gaps:

- empirical gap: interviews were conducted with insurance agents and sales managers of the most effective global and Polish life insurance corporations. This was the first time, on such a wide scale, that this had happened in the Polish and European market. The respondents were those who possessed the greatest achievements and experience, confirmed through the best sales results and those who possessed the highest authority resulting from the professional 
functions performed. The research allowed the opportunity of indepth insight into, and analysis of, the key drivers that determine the achievement of high effectiveness and competitive advantage. As regards this aspect, the results of this pioneering research constitute an essential contribution to European management science:

- theoretical gap: a summary of the American and European research achievements concerning the determinants that accompany the human resources management process in the areas of recruitment and selection, which creates new research challenges, and also constitutes a contribution to the enrichment of management sciences;

- methodological gap: the development of a formula to identify those factors that are advantageous to the improvement of the effectiveness of solutions for human resources management departments. Particularly in the area of recruitment, selection and retention of individuals with an optimal set of characterizations, ones that enable organizations to obtain the assumed level of effectiveness which is defined by the proposed dynamic measures of effectiveness based on praxeological assumptions.

\section{LITERATURE REVIEW}

\section{Coefficients of effectiveness in life insurance companies: a praxeological approach} As a result of an analysis of the indicators concerning the effectiveness of the operational activities of life insurance companies that have been functioning to date, it was possible to identify solely a quantitative and static perspective of effectiveness taking into consideration solely aggregated financial information whose values are established by law (Insurance Act, 2015). There was an exclusion of those factors that emphasize the significance of a qualitative perspective of effectiveness, which constitutes the results of the activities undertaken by insurance agents, and the significance of the value of relations created by them with customers for the effectiveness of insurance companies. Therefore, another conception for the effectiveness measures of life insurance companies was proposed. The conception accepted combines the praxeological (Gasparski, 2013) perspective of the effectiveness assessment of the activity of life insurance companies through the effectiveness of the professional activeness of insurance agents. Therefore, the author suggests that the effectiveness of life insurance companies needs to be characterized by other quantities connected indirectly or directly with the premium volume obtained from the sale of life insurances by agents, particularly by the number of appointments (relation agent - client) necessary to close the insurant contract (purchase policy). It should be emphasized that this solution highlights the significance of the individual activeness of single 
persons: entrepreneurs. In the context of the effectiveness of the whole organization, this is related to life insurance companies, which constitutes in a direct manner a reference to the praxeological assumptions, and also points to the defectiveness of statutory indexes based on a strictly statistical effectiveness perspective (Janowski, 2015).

Personality profile of an effective life insurance agent: FFM implementation An increase of the effectiveness level of first contact personnel in service organizations, whose operational activity is based on sales personnel, constitutes the subject of scientific research and special emphasis by managing personnel in the abovementioned companies (Verbeke, 2011). As a result, the scientific environment and its practitioners worked out a consensus that such factors as; knowledge connected with sales, adaptation sales, cognitive abilities, perception of the seller's role and motivation; decide about the effectiveness of the sales process. Although critical opinions do also appear, namely that these conclusions were inferred from statistical interactions between the seller and the customer (Evans, 2012).

Those life insurance companies where effectiveness is realized in the praxeological context constitute those companies where, in accordance with the laws of the Austrian school of economics, the personality traits of first contact personnel, insurance agents, are one of the main factors that determine the effectiveness of the sale of insurances. Hence, in order to conducted research, a model of the effectiveness assessment of the system of human resources management based on the fundamentals of the fivefactor theory was implemented, and consists of five personality dimensions:

Openness to experience: this is understood as a manifested tolerance towards difficulties appearing during stress causing professional situations, curiosity of innovative solutions, and low sensitivity towards the working environment which is characterized by a high amplitude of emotional strains (McCrae \& Costa, 2009). Individuals with a high level of openness frequently use external assessment tools that enable them to learn fast (Busato, Prins, Elshout \& Hamaker, 1999). Empirical research confirmed that openness is positively correlated with adaptability (LePine, Colquitt \& Erez, 2000). When employees go beyond organizational barriers, they do not use any unique processes or systems from the previous states of balance (Groysberg \& Lee, 2004), ones which they could find helpful in the present - a new organizational state. "Open" people are not set in traditions and norms established by social conformism (Judge \& Iles, 2002), and they tend to make changes and adapt easily to the social group in which they function (Wanberg \& Banas, 2000). Accordingly, I predict, 
Hypothesis 1: Life insurance company effectiveness will be positively associated with openness to experience.

Conscientiousness, in accordance with the opinion formulated by Costa and McCrae (2003), constitutes a trajectory of motivation to achieve goals, which to a significant degree extends the scope of individual adaptability (Pulakos, Arad, Donovan \& Plamondon, 2000). It was also found, in the empirical research, that conscientiousness is negatively correlated with absence from work, and it is reflected in self-discipline and a sense of responsibility (Wayne \& Musisca, 2004; Colquit \& Simmering, 1998; Ilies, Scott \& Judge, 2006). Therefore, this is a feature that determines the effectiveness of the use of time, organizational skills, an active approach to problem-solving and, consequently, a smaller susceptibility to stress at work (Wayne \& Musisca, 2004); it expresses the degree to which an individual maintains care and responsibility (Barrick \& Mount, 1991), which simultaneously enables an inspection of effects connected with the work of stressors in spite of previous negative experiences (Colbert et al., 2004). When a conscientious employee experiences negative stimuli, they refrain from non-productive behaviors to a greater extent than less conscientious people (Ilies, Scott \& Judge, 2006). Thus, I hypothesize,

Hypothesis 2: Life insurance company effectiveness will be positively associated with consciousness.

Agreeableness: individuals with a high level of this trait are compliant and oriented towards positive social interactions (Sherman, Nave \& Funder, 2015). They manifest channeled emotional reactions (Finch, Okun, Pool \& Ruehman, 1999). Ward et al. suggest that a tendency to compromise is a feature that determines the occurrence of depressions and the generation of a high level of stress in the context of challenges in the working environment. Furthermore, empirical research results demonstrate that a conciliatory manner is positively correlated with adaptability (Ward, Leong \& Low, 2004). Mount (see Marks, Zaccaro \& Mathieu, 2000) maintains that a tendency to compromise may lead to higher effectiveness at work as it supports interpersonal communication in the working environment, which is of key importance in an environment with a high amplitude of organizational changes, particularly in new situations. Many complex tasks in institutions require a high level of communication between employees, direct confrontation, solution of conflicts that are to settle a compromise: a consequence of a tendency to compromise (Gist, Stevens \& Bavetta, 1999). 
Hypothesis 3: Life insurance company effectiveness will be positively associated with extraversion.

Extraversion: in the opinion of Hogan (2007), this is a construct whose components include sociability (including exhibitionism and expression) and ambition (including initiative and impetus). Individuals with a high level of extraversion demonstrate a high level of sociability which enables them to obtain support from their friends to solve complex problems in their working environment (Wilt \& Revelle, 2009). As a consequence, they develop effective interpersonal relations that facilitate for them active membership in task groups (Rottinghaus \& Borgen, 2005). It was also identified that extraversion constitutes a factor that reduces the sensitivity of an individual to growing threats connected with their position at work, through a decrease in the level of counter-productive reactions to stressors (Robinson, Meier \& Vargas, 2005).

Hypothesis 4: Life insurance company effectiveness will be positively associated with extraversion.

Neuroticism: this includes anxiety, annoyance, hostility, depression, impulsiveness and sensitivity (Komarraju et al., 2011). It exerts a strong negative influence on psychological and socio-cultural adaptation, it accompanies depression and the individual's increasing problems (Widiger, 2009), while a lack of adaptation, which is characteristic of this trait, may constitute a consequence of a deficit in abilities and its negative impact on the efficiency of specific domains (Collings \& Mellahi, 2009; Eaton \& Bradley, 2009). People with high levels of neuroticism lack motivation in the majority of professions, and their work is characterized by a low level of effectiveness (Judge \& lles, 2002). Therefore, it is close to a negative attitude (Watson \& Clark, 2000) that is displayed in ineffective techniques that are copied to stress causing situations (Eaton \& Bradley, 2009). These authors claim the number of professions where the mentioned assumption are valid, is limited (excluding life insurance agent). In this context, an analysis was conducted on the personality profile of agents-entrepreneurs, based on the assumptions of the model referred to above.

Hypothesis 5: Life insurance company effectiveness will be positively associated with neuroticism. 


\section{RESEARCH METHODS}

The inductive method was implemented in the research because this utility is particularly useful and adequate as the conceptual base cannot determine identifiable dimensions in a simple manner (Williamson, Karp, Dalphin \& Grey, 1982). It requires an expert approach to an analysis of the sample content, is based on a post hoc factor analysis (Anderson \& Gebring, 1991; Kerlinger, 1986), and also asserts a correct categorization of factors (Ford \& MacCallum, 1986). Additionally, a comparative analysis of the subject literature increased the level of research results validation (Eisenhardt \& Graebner, 2007). The case study was constructed through the use of an iteration process, which was based on a consonance of theoretical assumptions and empirical evidence (Araujo \& Dubois, 2004; Dubois \& Gadde, 2002). The implementation of a case study in the context of theory development enhances inductive research through the creation of an adequate theory that creates scientific progress and is testable (Gibbert \& Ruigrok, 2010). The purpose of the conducted research was to identify whether the personality trait intensities of an effective life insurance agent are related to organizational effectiveness, perceived as his sales performance, in the example of life insurance companies.

\section{Participants and procedures}

The sample consisted of 812 of the most effective life insurance agents (according to the collected premiums for the 5 years preceding the research), whose results placed them in the top $10 \%$ of the whole workforce of each of the four companies (AVIVA, AMPLICO, NN, PZU and their Lithuanian branches), which possess the largest share in the market (combined 68.09\%) according to the acquired premiums in years 2011-2014. The sample was complete (every agent who met the criteria was covered by the research). The agents completed the 48 item Five Factor questionnaires constructed by P. Costa for this study. Each questionnaire was anonymous and put in an envelope when given to the researcher. A total of 812 sets of questionnaires were returned, with 16 being excluded due to extensive missing data or irregular patterns. The final response was $94.70 \%$. Background information: $39 \%$ male, $61 \%$ female, the majority of agents were aged between $30-50$ years (74\%); $59.80 \%$ had a college degree, $40.20 \%$ a graduate degree.

\section{Measures}

A personality questionnaire of the five-factor model constructed by Costa and McCrae (2003) based on the five-degree Likert scale was implemented in the research, ranging from 1 (strongly disagree) to 5 (strongly agree). The effectiveness of a life insurance company was measured by the number of 
agent's appointments with the customer prior to the purchase of the policy (this value was taken from the monthly reports of unit managers) for each company separately. This conception of the effectiveness is a determinant of human activity based on the Austrian School of Economics thinking. It reflects the relation between individual performance and organizational effectiveness (Von Mises, 2014). Territorial scope of the research: Poland, Lithuania (Polish branches) and duration of the conducted research: 2011-2014.

\section{ANALYSIS/STUDY/RESULTS}

\section{Data analyses}

The hypotheses were tested regarding the number of agent's appointments necessary to sell the life insurance policy. Independence tests related to the research, point to the occurrence of a statistically significant connection between the numbers of appointments held by the agent with the customer prior to the purchase of a policy. In the context of the determinants referred to above, an analysis was conducted on the personality traits of agentsentrepreneurs who completed the FFM questionnaire, together with their gender, age and education level. To test hypotheses, a multiple regression was conducted, with the individual number of agent's appointments (NONA) as the dependent variable, and personality traits, gender, age and education, as the independent ones. All the hypotheses were tested complex, excluding the redundant descripting variables.

\section{RESULTS}

Test of agent's performance - the differences between life insurance companies

The results of the abovementioned research are confirmed by an analysis of the average values of the number of the agent's appointments with the customer prior to the purchase of the policy: they differ significantly $\left(\aleph^{2}=131.15, \aleph^{2} \mathrm{HR}=137.91\right)$. AVIVA agents need on average 1.50 appointments for the conclusion of the contract with the customer. This result is statistically significantly higher than in the case of the remaining companies: PZU: 2.09, NN: 2.19 and Amplico: 2.32 (Table 1). 
Table 1. Sales efficiency of life insurance agents

\begin{tabular}{llllllllll}
\hline $\begin{array}{l}\text { Life } \\
\text { insurance } \\
\text { company }\end{array}$ & $\begin{array}{l}\text { market } \\
\text { share } \\
{[\%]}\end{array}$ & [n] & $*$ & SD & Mdn & \multicolumn{2}{l}{$\begin{array}{l}\text { LSD** } \\
\text { AVIVA AMPLICO NN }\end{array}$} & PZU \\
\hline AVIVA & 20.18 & 311 & 1.50 & .78 & 1 & - & .00 & .00 & .00 \\
AMPLICO & 7.04 & 62 & 2.32 & .74 & 2 & .00 & - & .43 & .14 \\
NN & 9.55 & 144 & 2.19 & 1.50 & 3 & .00 & .43 & - & .38 \\
PZU & 31.32 & 279 & 2.09 & 1.29 & 4 & .00 & .14 & .38 & -
\end{tabular}

Note: * average number of appointments necessary to sell a life insurance policy (NONA), $\boldsymbol{\aleph}^{2}=131.15$, $\aleph^{2} \mathrm{HR}=137.91,{ }^{* *}$ Bonferroni adjustment was implemented.

Tests of personality traits of FFM

The aim of this test was to find the level of trait intensities (Openness to experience, Consciousness, Extraversion, Agreeableness, Neuroticism) which characterize an effective life insurance agent (The maximum that trait intensity could reach was 100 , the minimum - 0). Descriptive statistics and correlations for the variables can be found in Table 2 .

Table 2. Descriptive statistics and correlations

\begin{tabular}{|c|c|c|c|c|c|c|c|}
\hline Variables & $M$ & SD & 0 & C & $E$ & A & $\mathrm{N}$ \\
\hline 0 & 41.41 & 19.49 & - & & & & \\
\hline C & 57.18 & 21.95 & .37 & - & & & \\
\hline$E$ & 61.75 & 20.36 & .52 & .38 & - & & \\
\hline A & 51.89 & 21.65 & .22 & .16 & .16 & - & \\
\hline $\mathrm{N}$ & 29.04 & 19.29 & -.22 & -.50 & -.46 & -.27 & - \\
\hline
\end{tabular}

For age, gender, and education level there was implemented $\mathrm{p}$-level. Hypotheses were tested with a series of least squares multiple regression. Table 3 includes the results for all hypotheses testing including the control variables.

Table 3. Openness to experience, consciousness, extraversion, agreeableness, neuroticism, age, gender and education level as predictors of job performance

\begin{tabular}{llll}
\hline Variables & & SE & P \\
\hline $\mathrm{O}$ & .195 & .005 & .000 \\
$\mathrm{C}$ & .981 & .010 & .000 \\
$\mathrm{E}$ & -.017 & .010 & .086 \\
$\mathrm{~A}$ & .131 & .012 & .001 \\
$\mathrm{~N}$ & .295 & .006 & .001 \\
\hline
\end{tabular}




\begin{tabular}{llll}
\hline Variables & & SE & P \\
\hline Age & .011 & .007 & .320 \\
Gender* & .149 & .112 & .171 \\
Education Degree & & & \\
College & .269 & .118 & .023 \\
Technical college & .372 & .090 & .000 \\
University & .345 & .080 & .000 \\
Technical University & -.145 & .115 & .207 \\
\hline = average bootstrapped regression coefficient, SE - bootstrapped standard error of , ${ }^{*}$ female $=0$, male $=1$, \\
n=796, significant $\mathrm{p}<.01$.
\end{tabular}

According to the trait "Openness to experience," results suggest that the intensity level of trait " $\mathrm{O}$ " is positively associated with the agent's performance $(=.195, p=.000)$. This supports Hypothesis 1 . Referring to "Consciousness", the mentioned trait intensity had a significant positive effect on an agent's effectiveness ( $=.981, p=.000)$. This supports Hypothesis 2 . On the contrary to abovementioned ones, based on the results ( $=-.017, p=.086)$, trait „E" should not be taken into consideration in the context of a life insurance agent's effectiveness (statistically insignificant). It does not support Hypothesis 3. Whereas, a relation of "Agreeableness" intensity and agent's performance level is positive but weak ( $=.131, p=.001)$. It supports Hypothesis 4 . Finally, in the context of the trait "Neuroticism", results prove that the intensity level of trait " $\mathrm{N}$ " is positively associated with an agent's performance $(=.295$, $\mathrm{p}=.001$ ). This supports Hypothesis 5 . Moreover, it is particularly important to recruit individuals with a technical college $(=.372, p=.000)$ or university $(=.345, p=.000)$ degree to achieve the competitive advantage.

\section{DISCUSSION}

The main purpose of the study was to provide a confirmatory analysis of the relation between the personality traits of life insurance agents and their job performance by only including scales that were explicitly designed to measure the Big Five personality dimensions. The results were highly consistent with the original paper of Barrick and Mount (1991), in that "conscientiousness" was identified to have the highest validity of the Big Five dimensions of overall job performance. Conscientious sales representatives are more likely to strive for accomplishments (Bratton \& Gold, 2017). It is also noteworthy that there is almost a directly proportional dependence between life insurance sales effectiveness and the traits of openness to experience 
and neuroticism. These findings correspond to the recent analyses of Funder (2006), Behling (1998) and Uppal and Mishra (2014). Personality is likely to be the critical dispositional basis for determining how the person interacts or is motivated once an individual has chosen an environment, that is consistent with one's interest (Judge \& Ilies, 2002). The authors claim that people high in Conscientiousness and Neuroticism (Emotional stability) are more likely to set goals, have higher expectations that their efforts will determine favorable consequences, and think they can do more (have higher self - efficacy) than those low in these cited traits. Enhanced performance motivation, in turn, is expected to be an important predictor of performance (Ilies, Keeney \& Scott, 2011). There are criticisms also. Furnham (2008) claims that agreeableness, neuroticism, and an openness to experience, were not found to be positively correlated with sales performance. The mentioned results were conducted in the FMCG market. A life insurance policy, according to Rogozinski (2012), is not a physical product but is a promise of payment of cash benefits in the case of death or reaching retirement age; hence, decision-making criteria concerning its purchase are different in the case of policies. Contrary to expectations, the analysis showed that the level of extraversion intensity is not correlated to sales efficiency. According to the previous research of Barrick (2001), Bing and Lounsbury (2000) and Vinchur et al. (1998), it was found that Extraversion was a valid predictor of performance in jobs characterized by social interaction, such as sales personnel and managers. However, these authors did not take life insurance agents into consideration in their research. Hence, it is difficult to relate, in an explicit manner, their conclusions to the specificity of the life insurance market.

Between the traits of Conscientiousness (Hobfoll \& Wells, 1999) and Agreeableness (McCrae \& Costa, 2003), the determinant of effectiveness by their occurrence is perceptible only and solely in the situations of strictly defined intensities which, if exceeded, may cause its abrupt reduction.

The research results also reveal that age and gender are not statistically significant for life insurance company effectiveness. Referring to education level, a legal regulation exists which obliges a person who is applying for work as an insurance agent to possess secondary education as a minimum. Nevertheless, in order to recruit people with a higher potential probability of successful professional achievement, seeking people with a secondary technical education or higher education is justifiable.

Implicitly or explicitly, the model of Costa and McCrae developed and tested in this study, received general support. A direct comparison of the variables comprising theoretical explanations suggested that the trait activation theory may be relatively important in explaining when and how personality trait intensity is predictive of job performance. While some have 
questioned the practical relevance of personality variables for human resource selection decisions (Joyce \& Slocum, 2012; Murphy \& Dzieweczynski, 2005), the results imply, when there is reason to believe that the trait is relevant to the job context, that validities cannot be characterized as "disappointingly low" (Schmitt, 2004) to any but the most captious observer. In responding to Morgeson's (2007) critique of the personality-performance literature, Tett and Christiansen (2007) claimed, "The ideal situation for any worker is one providing opportunities to express his or her traits...such that trait expression is valued positively by others" (Judge \& Zapata, 2014, p. 1168).

\section{CONCLUSION}

The five-factor model is limited in this study to the degree to which personality trait intensities express themselves in job performance. Beyond job analysis, little is known about the situational determinants or what variables are useful when comparing one situation with another (Judge \& Zapata, 2014). Today, a framework for characterizing the psychology based aspects of a situation is a key factor method for assessing the above-mentioned variables. Moreover, future researchers must examine the process through which personality affects behavior at work. As claimed earlier, researchers must take into account the characteristics of a work environment. This is a little removed from the degree to which personality expresses itself, and to which it expresses itself in behavior. While this approach was appropriate given the goals of the study, it is also important for future research to link how situations impede or activate the expression of traits, and how these traits are manifest in specific job behaviors that, in turn, lead to effectiveness. There are situations, for example, that influence the degree to which an extravert premiums or behaves like an extravert, just as there are situations that an extravert may find more motivating, or more likely to produce assertive behaviors than others. These sorts of expressions are distinct from (but often related to) job effectiveness, and the situational traits that lead to these kinds of expressions may be different from those which lead to effectiveness. As a consequence, this study has some limitations that require discussion. It does not exhaust the list of trait-relevant cues that might moderate personality job performance relationships. In the study, the focus was on the job, or taskbased cues, but there are other factors that may be relevant, such as human resource systems, and organizational culture (Judge \& Zapata, 2014). Future research might study those variables as situational moderators as well. The next issue future researchers should focus on is measurement problems. If it is not possible to guarantee the highest degree of precision, the results 
obtained will always be disputable. In this context, it is important to accept an assumption concerning the permanence of personality traits (McCrae \& Costa, 2003), and the response to items on a personality inventory, at any one moment, is determined by many traits, states and features of the immediate situation. Consequently, traits usefully predict behavior only when it is aggregated (Pacini \& Epstein, 1999), either over a category of behaviors (e.g., counterproductive behavior) or across time (annual performance or longer). It is also important to underline that the global traits (e.g., BIG FIVE) are best for explanation and theory development; however, prediction of narrower and more specific behaviors at work will require correspondingly narrower trait constructs (Brown et al., 2016). Effective measurement considers addressing both of these concerns; therefore it is reasonable to claim that personality traits can explain behaviour at work, particularly when it is aggregated across time and job situation. Personality indicates impressive consistencies over time even if a person's life situation changes (McCrae \& Costa, 2003), in a manner that can provide valuable information about what the individual is likely to do at work.

\section{References}

Act of 11 Sept. (2015) on insurance and reinsurance operations. Journal of Laws from the year 2015, Item 1844.

Araujo, L.M., \& Dubois, A. (2004). Research Methods in Industrial Marketing Studies (pp. 207-228). Wiley: Chichester.

Barrick, M. R., Mount, M. K., \& Judge, T. A. (2001). Personality and performance at the beginning of the new millennium. What do we know and where do we go next. Personality and Performance 9(1/2), 9-30.

Barrick, M., \& Mount, M. (1991). The Big Five personality dimensions and job performance: A meta-analysis. Personnel Psychology, 44, 1-26.

Behling, O. (1998). Employee selection: Will intelligence and conscientiousness do the job? Academy of Management Executive, 12, 77-86.

Bing, M.N., \& Lounsbury, J. (2000). Openness and job performance in U.S.-based Japanese manufacturing companies. Journal of Business and Psychology, 14, 515-522.

Bratton, J., \& Gold, J. (2017). Recruitment, Selection and Talent Management. Human Resource Management (pp. 140-182). USA: Springer.

Brown, L.E., Weiss, S, Roberts, R., Birney, D.P., \& MacCann, C. (2016). Conscientiousness and agreeableness predict the difference between typical-behavior and maximum-effort emotion management. Personality and Individual Differences, 101, 470.

Busato, V., Prins, F., Elshout, J., \& Hamaker, Ch. (1999). The relation between learning styles, the Big Five personality traits, and achievement motivation in higher education. Personality and Individual Differences, 26, 129-140. 
Buss, D.M. (2009). An evolutionary formulation of person-situation interactions. Journal of Research in Personality, 43, 241-242.

Christiansen N., Tett, R. (2007). Personality tests at the crossroads: A response to Morgeson, Campion, Dipboye, Hollenbeck, Murphy, and Schmitt. Personnel Psychology, 60(4), 967-993.

Colbert, A., Mount, M., Harter, J., Witt, L., \& Barrick, M. (2004). Interactive effects of personality and perceptions of the work situation on workplace deviance. Journal of Applied Psychology, 89, 599-609.

Collings, D. G., \& Mellahi, K. (2009). Strategic talent management: A review and research agenda. Human Resources Management Review, 19, 304-313.

Dubois, A., \& Gadde, L.E. (2002). Systematic combining: An abductive approach to case research. Journal of Business Research, 55(7), 553-560.

Eaton, R., \& Bradley, G. (2009). The role of gender and negative affectivity in stressor appraisal and coping selection. International Journal of Stress Management, 15(1), 94-115.

Eisenhardt, K.M., \& Graebner, M.E. (2007). Theory building from cases: Opportunities and challenges. The Academy of Management Journal, 50(1), 25-32.

Evans, K. (2012). Advancing Sales Performance Research: A focus on five under researched topic areas. Journal of Personal Selling and Sales Management, 32(1), 89-106.

Finch, J., Okun, M., Pool, G., \& Ruehlman, L. (1999). A comparison of the influence of conflictual and supportive social interactions on psychological distress. Journal of Personality, 67, 581-621.

Ford, J.K., MacCallum, R.C., \& Tait, M. (1986). The application of exploratory factor analysis in applied psychology: A critical review and analysis. Personnel Psychology, 59, 291-314.

Funder, D.C. (2006). Towards a resolution of the personality triad: Persons, situations, and behaviours. Journal of Research in Personality, 40, 21-34.

Furnham, A. (2008). Personality and Intelligence at Work. New York: Routledge. Gasparski, W. (2013). Human action as an ultimate given: Ludwig von Mises' praxeology as seen from a business ethics angle. Studia Humana, 2(1), 3-14.

Gibbert, M., \& Ruigrok, W. (2010). The "what" and "how" of case study rigor: Three strategies based on published work. Organizational Research Methods, 13(4), 710-737.

Gist, M., Stevens, C., \& Bavetta, A. (1999). Effects of self-efficacy and posttraining intervention on the acquisition and maintenance of complex interpersonal skills. Personnel Psychology, 44, 837-861.

Groysberg, B., \& Lee, L. (2009). Hiring stars and their colleagues: Exploration and exploitation in professional service firms. Organization Science, 20(4), 740-758.

Hobfoll, S.E., \& Wells, J.D. (1998). Conservation of resources, stress, and aging: Why do some slide and some spring. In J. Lomranz (Ed.). Handbook of Aging and Mental Health: An Integrative Approach. New York: Free Press. 
Hogan, R. (2007). Personality and the fate of organizations. Personnel Psychology, 60(4), 1051-1087.

Ilies, R., Keeney, J., \& Scott, B. (2011). Work-family interpersonal capitalization: Sharing positive work events at home. Organizational Behavior and Human Decision Processes, 114, 115-126.

Ilies, R., Scott, B., \& Judge, T.A. (2006). The interactive effects of personal traits and experienced states on intra-individual patterns of citizenship behavior. Academy of Management Journal, 49, 561-575.

Janowski, A. (2015). The development of Polish life insurance market in the context of Austrian school - client's approach. British Journal of Economics, Management \& Trade, 5, 132- 143.

John, O.P., \& Gross, J.J. (2007). Individual differences in emotion regulation. In J.J Gross (Ed.). Handbook of Emotion Regulation. New York: Guilford Press.

Joshi, A., \& Roh, H. (2009). The role of context in work team diversity research: A meta-analytic review. Academy of Management Journal, 52, 599-627.

Joyce, W.F., \& Slocum, J.W. (2012). Top management talent, strategic capabilities and firm performance. Organizational Dynamics, 41, 183-193.

Judge, T., \& Zapata, C. (2014). The Person-situation debate revisited: Effect of situation strength and trait activation on the validity of the big five personality traits in predicting job performance. Academy of Management Journal, 58(4), 1149-1179.

Judge, T.A., \& Ilies, R. (2002). Relationship of personality to performance motivation: A meta-analytic review. Journal of Applied Psychology, 87, 797-807.

Kerlinger, F. (1986). Foundations of Behavioural Research. New York: Holt, Rinehart, Winston.

Komarraju, M., Karau, S., Schmeck, R., \& Avdic A. (2011). The Big Five Personality traits, learning styles, and academic achievement. Personality and Individual Difference, 51, 472-477

LePine, J., Colquitt, J., \& Erez, A. (2000). Adaptability to changing task context: Effects of general cognitive ability, conscientiousness, and openness to experience. Personnel Psychology, 53, 563-593.

Lucas, R.E., \& Donnellan, M.B. (2009). If the person- situation debate is really over, why does it still generate so much negative affect? Journal of Research in Personality, 43, 146-149.

Marks, M., Zaccaro, S., \& Mathieu, J. (2000). Performance implications of leader briefings and team-interaction training for team adaptation to novel environments. Journal of Applied Psychology, 85, 971-986.

McCrae, R., \& Costa, P. (2003). Personality in adulthood: A five-factor theory perspective (2nd ed.). New York: Guilford Press.

McCrae, R.R., Sutin, A.R. (2009). Openness to experience. In M.R. Leary \& R.H. Hoyle (Eds.). Handbook of Individual Differences in Social Behavior (pp. 257-273). New York: Guilford. 
Harasym, R, Rodzinka, J \& Skica, T (2017). The size of local government administration at a municipal level as a determinant of entrepreneurship. Journal of Entrepreneurship, Management and Innovation, 13(2), 5-32.

Mises L. Von. (2014). Economic Calculation in the Socialist Commonwealth. Alabama: Mises Institute.

Morgeson, F.P, Campion, M.A., Dipboye, R.L., Hollenbeck, J.R., Murphy, K., \& Schmitt, N. (2007). Are we getting fooled again? Coming to terms with limitations in the use of personality tests for personnel selection. Personnel Psychology, 60, 1029-1049.

Murphy, K.R., \& Dzieweczynski, J.L. (2005). Why don't measures of broad dimensions of personality perform better as predictors of job performance. Human Performance, 18, 343-357.

Ones, D.S., Dilchert, S., Viswesvaran, C., \& Judge, T.A. (2007). In support of personality assessment in organizational settings. Personnel Psychology, 60, 995-1027.

Pacini, R., \& Epstein, S. (1999). The relation of rational and experiential information processing styles to personality, basic beliefs, and the ratio-bias phenomenon. Journal of Personality and Social Psychology, 76, 972-987.

Pulakos, E., Arad, S., Donovan, M., \& Plamondon, K. (2000). Adaptability in the workplace: Development of a taxonomy of adaptive performance. Journal of Applied Psychology, 85, 612-624.

Roberts, B.W. (2009). Back to the future: Personality and assessment and personality development. Journal of Research in Personality, 43, 137-145.

Robinson, M., Meier, B., \& Vargas, P. (2005). Extraversion, threat categorizations, and negative affect: A reaction time approach to avoidance motivation. Journal of Personality, 73, 1397 -1436.

Rogozinski, K. (2012). Zarzqdzanie Wartościq z Klientem [Managing the Value with Client]. Warsaw: Wolters Kluwer.

Rottinghaus, P., Borgen, F.H., \& Day, S.X. (2005). The career futures inventory: A measure of career-related adaptability and optimism. Journal of Career Assessment, 13, 3-24.

Sherman, R.A., Nave, S.C., \& Funder, D.C. (2015). Personality-driven situation experience, contact, and construal: How people's personality traits predict characteristics of their situations in daily life. Journal of Research in Personality, 55, 98-111.

Trevino, L.K. (1986). Ethical decision making in organizations: A person-situation interactionist model. Academy of Management Review, 11, 601-617.

Uppal, N., Mishra, S., \& Vohra, N. (2014). Prior related work experience and job performance: Role of personality. International Journal of Selection and Assessment, 22(1), 39-51.

Verbeke, W., Dietz, B., \& Verwaal, E. (2011). Drivers of sales performance: A contemporary meta-analysis. Have salespeople become knowledge brokers? Journal of the Academy of Marketing Science, 39(3), 407-428. 
Vinchur, A.J., Schippmann, J.S., Switzer III, F.S., \& Roth, P.L. (1998). A metaanalytic review of predictors of job performance for salespeople. Journal of Applied Psychology, 83, 586-597.

Wanberg, C., \& Banas, J. (2000). Predictors and outcomes of openness to changes in a reorganizing workplace. Journal of Applied Psychology, 85, 132-142.

Ward, C., Leong, C., \& Low, M. (2004). Personality and sojourner adjustment: An exploration of the big five and the cultural fit proposition. Journal of Cross-Cultural Psychology, 35, 137-151.

Watson, D., \& Clark, L. (1997). Extraversion and its positive emotional core. In R. Hogan, J. Johnson \& S. Briggs (Eds.). Handbook of Personality Psychology (pp. 767-793). San Diego: Academic Press.

Wayne, J., Musisca, N., \& Fleeson, W. (2004). Considering the role of personality in the work-family experience: Relationships of the big five to work-family conflict and enrichment. Journal of Vocational Behavior, 64, 108-130.

Widiger, T. (2009). Neuroticism. Handbook of Individual Differences in Social Behavior. New York: Guilford.

Williamson, J.B., Karp, D.A., Dalphin, J.R., \& Grey, P.S. (1982). The Research Craft. Boston: Little, Brown.

Wilt, J., \& Revelle, W. (2009). Extraversion. Handbook of Individual Differences in Social Behavior. New York: Guilford.

Wirdamulia, A., \& Afiff, A.Z. (2013). Expanding brand personality congruence to brand personality fit: The importance of customer value proposition as a moderating fit on brand performance. ASEAN Marketing Journal 5(2), 69-82.

\begin{abstract}
Abstrakt
W organizacjach w uprzemysłowionych krajach, jakość zasobów ludzkich stanowi główny problem na drodze do uzyskania przewagi konkurencyjnej. Implementacja modelu pięcioczynnikowego Costy i McCrae'a dostarcza rozwiqzania dla wzmiankowanego problem. Celem niniejszego artykułu jest ukazanie kluczowej roli implementacji modelu pięcioczynnikowego Costy i McCrae'a dla efektywności zakładu ubezpieczeń na życie zarówno z perspektywy teoretycznej, jak i praktycznej. Badanie w tej pracy oparto na stadium przypadku czterech największych zakładów ubezpieczeń na życie. Próbę stanowiło 796 najbardziej efektywnych agentów ubezpieczeniowych. W badaniu posłużono się kwestionariuszem modelu pięcioczynnikowego. Wyniki wskazuja na istnienie pozytywnej korelacji pomiędzy poziomem natężenia niektórych cech osobowości i skutecznościq sprzedażowq agentów ubezpieczeniowych. Poziom natężeń cech "otwartość na doświadczenie", "sumienność", "ugodowość" i "neurotyzm" stanowi korelatę efektywności zakładu ubezpieczeń na życie. Co więcej, wyniki badań wskazujq na istnienie podstaw do ich indukcji do systemów zarzqdzania całego sektora finansowych usług detalicznych.
\end{abstract}

Słowa kluczowe: przewaga konkurencyjna, efektywność, skuteczność ludzka, zarzqdzanie, organizacja, cechy osobowości. 


\section{Biographical note}

Andrzej Janowski - Doctor of Economic Sciences in the field of management sciences. Specialization: human resources management, insurance; sales director and insurance broker of Nord Partner Ltd. Scientific interests: human resources management effectiveness, particularly in the context of talent management in life insurance organizations. The author of the integrating talent management model in Europe. 